
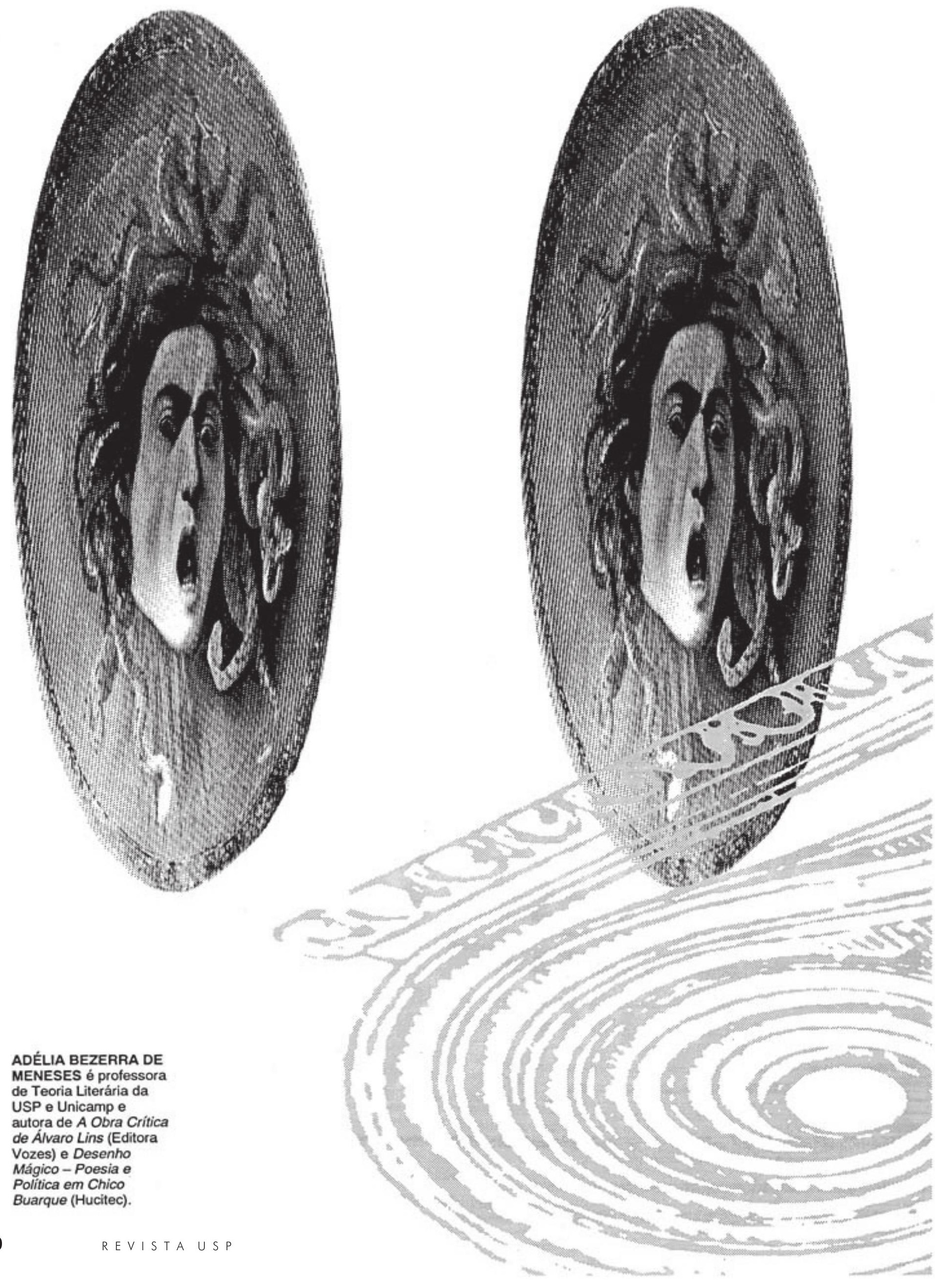


\section{A serpente}

sou eu

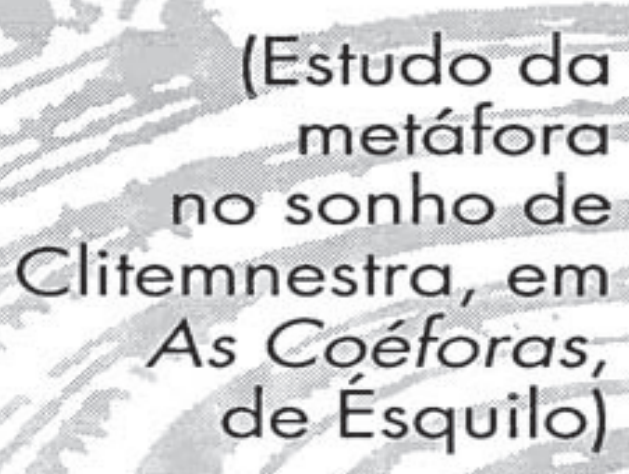

Uma peça na qual o cenário é dominado pelo túmulo de um pai, túmulo que se transformará quase que numa personagem; uma peça em que campeia, avassaladora, a angústia; em que o entrecho gira em torno de um matricídio, cometido por um filho, mas insuflado pela filha, possuída deum ódioentranhado à mãe; uma peça, finalmente, que contém um sonho que a estrutura, sonhado por uma das personagens e imediatamente interpretado por outra, que nela se vêsimbolizada, e que se esmerará por fazê-lo cumprir-se: As Coéforas de Ésquilo são um prato cheio para psicanálise. Talvez até cheio demais, com risco de indigestão. Por isso, não vou pretender explorar todos os seus elementos (vã pretensão, aliás), mas vou-me debruçar sobre um deles - com a consciência, por sinal, de que, querendo ou não, através desša ponta, todo o novelo se desdobrará. E esse elemento é o sonho de Clitemnestra, ao qual se faz referência já na primeira cena da tragédia. Com efeito,os 
versos iniciais aludem a um sonho ameaçador que a rainha tivera. Diz o coro:

"En un trop clair langage, auquel se dressent les cheveux, le prophète qui, dans cette demeure, parle par la voix des songes, soufflant la vengeance du fond dusommeil, en pleine nuit, au coeur du palais, proclamant son oracle en un cri d'épouvante, lourdement vient de s'abattre sur les chambres des femmes. Et, interprétant cessonges, des hommes dont la voix a les dieux pour garants ont proclamé que, sous terre, les morts aprementseplaignentets'irritent contre leurs meurtriers" (v. $32 \mathrm{ss)} \mathrm{(1).}$

Estamosmergulhadosnumclimadeobscuros presságios, de angústias sem fundo, da presença fantasmática de um morto não vingado, cujo túmulo domina o cenário, $\mathrm{e}$ cuja presença rouba a cena dos demais protagonistas.

A primeira questão que este trecho apresenta - um problema de estabelecimento textual interessante - é que, dizem os helenistas (2), os manuscritos apresentam um texto metricamente inaceitável, onde figura o termo Phoibos (= Febo, Apolo, oráculo), que alguns especialistas substituemporPhobos (=medo). Phoibos/Phobos: importaria precisar qual o termo originalmente empregado? E irretorquível que as duas idéias, de oráculo e de medo, em sua interassonância no original grego, estão intensamente presentes e respaldadas pelo contexto. Diz Jacqueline Romilly, que dedicou um livro ao problema do medo e da angústia no teatro de Ésquilo, que aqui o medo, personificado, toma voz. O grito de pavor de Clitemnestra (que será retomado no v. 535) identifica-se com a voz deste "profeta dos sonhos": ambos redutíveis a uma manifestação do inconsciente. Aliás, para esta autora o medo esquiliano, na sua brutalidade incontrolada, testemunharia o quanto os gregos admitiam todo um mundo de forças irracionais.

Mas embora a tragédia se inicie com essa referência ao sonho de Clitemnestra, é só posteriormente, no exato centro do drama (3), que ele será relatado pelo Corifeu (e interpretado por seu interlocutor). No entanto, ao longo de mais de 500 versos, ele permanecerá surdamente como pano de fundo, ameaçador e sombrio, contribuindo para a angústia difusa que impregna o ambiente, intensificando o clima de sinistros

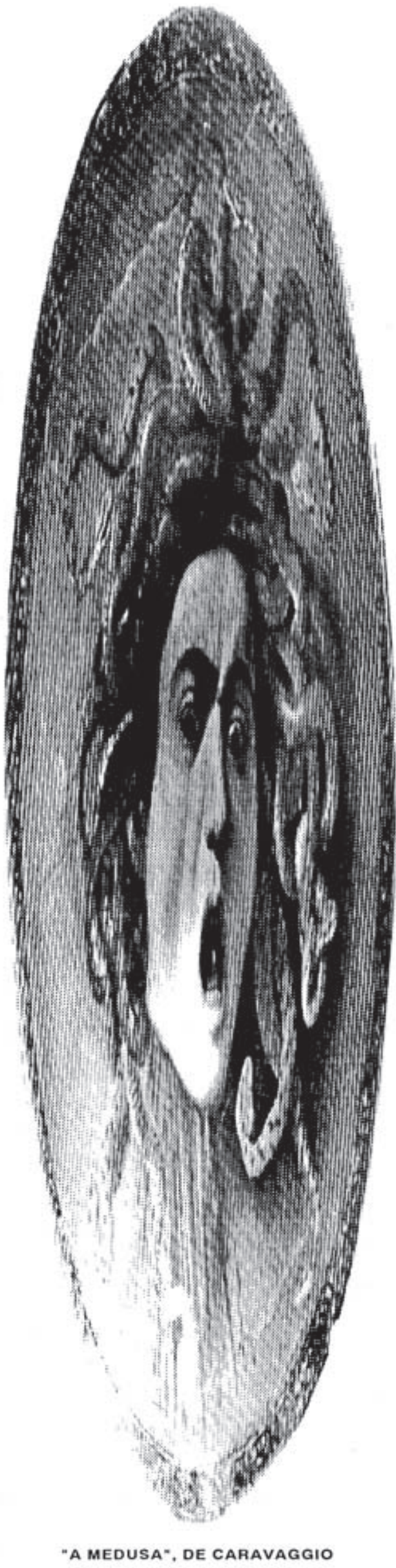


augúrios: pois, se não nos foi revelado ainda seu conteúdo, sabemos já de sua significaçäo: "sous terre, les morts âprement se plaignent et s'irritent contre leurs meurtriers" (v. 39).

E aqui impōe-se um parêntese. A compreensão desse enredo exigirá que se leve em conta não apenas a peça em questão, $A s$ Coéforas, mas que recuemosà primeira tragédia da trilogia na qual ela se insere, a Orestíada (composta por Agamenon, As Coéforas e As Eumênides), integrando um mesmo conjunto lendário.

$\mathrm{Na}$ primeira das peças da trilogia, Agamenon, narra-se a volta do rei dos Atridas a seu palácio, onde sua mulher Clitemnestra - profundamente ferida pelo sacrifício, dez anos atrás, de Ifigênia (imolada pelo pai como condição para que os deuses permitissem a partida das tropas dos aqueus para a guerra de Tróia) - o espera com rancor no coração. Assim, logo que Agamenon desembarca vitorioso, de volta de Tróia, Clitemnestra, ajudada pelo amante Egisto, lança sobre ele uma rede que o imobiliza $\mathrm{e} \mathrm{o}$ assassina, $\mathrm{a}$ ele $\mathrm{e}$ à profetiza Cassandra, presa de guerra e amante do rei. Apeça termina com o Coroevocando Orestes, o filho: "A moins qu'un dieu ne guide Orestejusqu'ànous!'(Agamenon, v.1667).

É este ogancho que se estabelecerá com a segunda peça, As Coéforas. Sete anos após esses acontecimentos, Orestes, que era menino por ocasiảo do assassinato de seu pai, e que fora então afastado de Argos por sua irmã Electra, retorna, chegado à idade de homem, para reconquistar seus direitos. Insuflado por Apolo, que lhe comanda a Vingança, ele se dirige imediatamente ao túmulodopai.Enomomentoem que depōe como oferenda um anel de seus cabelos, percebe aproximar-se um cortejo de mulheres, encabeçado por sua irmā. Com efeito Clitemnestra, inquieta por um sonho ameaçador, viu-se impelida a tentar pacificar a alma do morto, e encarrega Electra de tal missão. Após a cena famosa do reconhecimento dos dois irmãos, e após a prece que ambosendereçam aopai morto (que sóentão é chorado como manda o rito) e a quem lembram que, na morte, ele sobrevive através de seus filhos, Orestes pergunta ao Corifeu por que teria Clitemnestra enviado libações ao túmulo de Agamenon, "tentando pacificar tarde demais um mal que nāo tem cura". Com a resposta do Corifeu, trava-se um diálogo entre os dois, através do qual o sonho é narrado:
"Corifeu. - ... Ce sont des songes, des terreurs inquiétant ses nuits, qui l'ont fait sauter de sa couche pour envoyer ces libations, la femme impie!

Oreste. - Mais le songe lui-même, peuxtu me le conter?

Corifeu. - Elle crut enfanter un serpent (4), disait-elle.

Oreste. - Dis-moi la fin: comment se termine ce rêve?

Corifeu. - Elle, comme un enfant, l'abritait dans des langes.

Oreste. -Et de quoi vivait-il, le monstre nouveau-né?

Corifeu. - Elle-memê, en son rêve, lui présentait le sein.

Oreste. -Et le seinn'était pas blessé par un tel monstre?

Corifeu. -Si! un caillot de sang semêlait à son lait.

Oreste. - Voilà qui pourrait bien n'être pas un vain songe!

Corifeu. - Elle s'éveille et pousse un cri d'effroi. Et aussitôt les torches, à qui l'ombre avait fermé les yeux, dans la maison jaillissent en foule à la voix de la maütresse. C'est alorsqu'elleenvoieces offrandes funèbres, espérant y trouver le remède à ses maux" (v. 523-39).

Até aqui, o relato "objetivo" do sonho, construído com a ajuda das intervenções de Orestes, que aí intercala também o seu desejo: "Voilà qui pourrait bienn'être pas un vain songe!".

Mas a sequêencia do diálogo é extremamente importante: o interlocutor se vê concernido pelo sonho, apresenta-se como uma de suas personagens e o interpreta, aí inscrevendo seu desejo:

“Oreste. - Eh bien! je prie la Terre qui nous porte, je prie le tombeau de mon père de me laisser réaliser ce songe. Voyez, je l'interprète en le serrant de près: si, sorti du même sein que moi, ce serpent (5a), ainsi qu'un enfant, s'est enveloppé de langes, a jeté ses lèvres autour delamamellequijadismenourrit et au doux lait d'une mère a mêlé un caillot de sang - tandis qu'elle, effrayée, criait de douleur - il faut, comme elle l'a donné au monstre qui l'épouvanta, qu'elle me donne aussison sang. et c'est moi -le serpent! (5b) - c'est moi qui la tuerai, ainsi que le prédit son rêve" (v. $540)$.

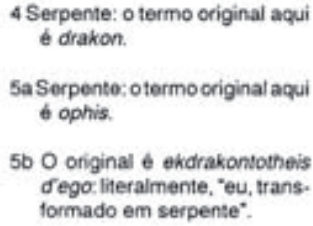


Estabelece-se uma inversão: Orestes se apropria do sonho da mãe, é como se ele o tivesse sonhado, e o desenvolvimento da peça nada mais será que a realização desse sonho - que ele se imporá como uma missāo. Sim, o sonho é a realização do desejo de Orestes: masqual desejo? Odesejoconsciente de matar a mãe, cumprindo a lei do talião e a ordem de Apolo, ou o desejo de possuí-la sexualmente, no coito sádico que os psicanalistas (6) vêem figurado na imagem da serpente que morde o seio da mulherque a parira? Um sonhojádecodificado, já interpretado: qual seria o sentido de abordá-lo? Minha proposta, noentanto, não vai por aí. É que tal sonho - absolutamente central na tragédia, e que, como eu já disse, num certo sentido a estrutura - fornece margem para um estudo da simbologia, da metáfora, que eu gostaria de empreender: especificamente, da metáfora da serpente, em toda a sua riqueza de desdobramentos.

Um caminho extremamente interessante seria rastrear essa imagem do sonho de Clitemnestra ao longo da peça em que ele surge, ao mesmo tempo em que no imaginário grego clássico. Uma primeira observação quanto a este levantamento diz respeito à riqueza e diversidade de termos utilizados no grego, n'As Coéforas, para "serpente": echidna (v. 249 e v. 994: nos dois casos, aplicados a Clitemnestra, na acepção de víbora); drakon (v. 527, v. 549, v. 1047 e v. 1049); ophis (v. 543 e 928). E se formos sair da tragédia esquiliana e ampliarmos o campo para o mundo grego em geral, a lista cresce. $\mathrm{O}$ tradutor francês da Oneirocrítica de Artemidoro de Daldis, Festugière, em nota de rodapé ao item "Répteis"doextraordinário "TratadodeSonhos" da Antigüidade, elenca vários sinônimos: drakon (Pytho ou jibóia), ophis (toda espécie de serpente), aspis (áspide), echidna (víbora), hydros (cobra), drü̈nas (vibora que se esconde nas raízes dos carvalhos ocos), pareïas (cobra "bochechuda" que freqüentava os santuários de Epidauro), physalos (uma espécie de sapo venenoso), seps (uma espécie de vibora, sobre a qual os antigos não estão de acordo), dipsas (uma serpente muito venenosa, cuja mordida dá uma sede atroz), diphas (o mesmo que dipsas) (7). Tal variedade sinonímica (que faz lembrar os termos variadíssimos que o GrandeSertão: Veredas de Guimarães Rosa apresenta para dar conta de "diabo")sóvem a mostrar a presença marcante dessa realidade no imaginário grego.
Mas o que "serpente" poderia vir a significar, em As Coéforas, no sonho de Clitemnestra? Descartemos, de início, opor demais evidente símbolo fálico que ela sugere. Se nos puséssemos na pele da rainha - melhor dizendo, na sua psique cultural - a primeira associação talvez fosse "animal ctônico". A serpente, entre os antigos, representava algo vindo do mundo dos mortos, das regiốes subterrâneas, do mundo infernal. Sobre a serpente, diz Artemidoro de Daldis que "pour ainsi dire il mène à la terre, car il est lui-même aussi fils de la terre et il a son séjour dans la terre" (Oneirocrítica, II, 13).

Dessa perspectiva, a serpente representaria Agamenon, o marido assassinado, na mesma medida em que, na Eneida, o pai morto de Enéias, Anquises, surge figurado por uma serpente em meio ao sacrifício de celebração de um ano de sua morte, oferecido junto ao seu túmulo:

"Il (Enée) achevait ses mots quand, sorti des saintes profondeurs du sépulcre, un reptile luisant, qui traênait immense sept anneaux, sept replis, enlaça tranquillement la tombe et se laisse glisser au milieu des autels. (...) A cette vue Enée est frappé de stupeur. Enfin le reptile se déroule en rampant à travers les patères et les coupes brillantes; il goûte aux mets sacrés et rentre, inoffensif, au fond du tombeau, abandonnant les autels où les offrandes sont consummées" (Eneida, Canto V,v. 82 - trad. de A. Bellesort).

Tal é, aliás, a interpretação que os oneiromantes (aqueles que predizem o futuro a partir dos sonhos) de As Coéforas fazem no início da peça, no já referido trecho dos versos 39 ss: sous terre, les morts âprement se plaignent et s'irritent contre leurs meutriers".

É essa também a interpretação inequívoca de Clitemnestra, uma vez que a rainha, após despertar, envia libaçōes aplacatórias ao túmulo de Agamenon. O matricídio-realização cabaldo sonho-será, assim, obra do morto, será guiado pelas potênciasinfernais.Sabíamos, até entāo, que a ordem de vingar o pai provinha de Apolo, e do próprio Zeus. A partir de agora temos não apenas os deuses olímpicos - Apolo à testa - a insuflar a vingança em Orestes, mas também as divindades infernais, do mundo ctônico, manifestadas através do sonho, 
irrupção da esfera do demoníaco (8). Diz Karl Reinhardt que, enquanto na Odisséia só se conhecia, a respeito desse mito, a autoridade olímpica a instigar o braço vingador de Orestes, aqui na tragédia - e essa é uma marca do próprio Ésquilo - surge esse outropoder instigador, simétrico e complementar, das potências das profundezas: "assim, duas motivaçōes diversas se chocam, e esta dualidade de origem é o que empresta ao crime sua verdadeira ambivalência" (9a).

Mas antes de aprofundar o estudo do sonho de Clitemnestra, eu gostaria de, saindo um pouco do sonho, rastrear a metáfora da serpente na tragédia, articulando-a, como já tinha proposto, ao imaginário grego em geral.

E, surpreendentemente, em seu primeirosurgimenton'As Coéforas, a metáfora da serpente diz respeito a Clitemnestra, sendo Agamenon aífiguradocomo “águia”. Aqui, a vibora infame é Clitemnestra, que matou a águia real e agora ameaça sua ninhada. Ainda no início da peça, quando os dois irmãos se reconhecem ao pé do túmulo paterno, Orestes, emocionado pelo encontro, eleva a Zeus uma prece:

"Zeus, Zeus, viens contempler notre misère.

Vois: les petits de l'aigle ont perdu leur père; il est mort dans les replis, les noeuds d'une vipère $(9 \mathrm{~b})$ infâme, et la faim dévorante presse sesorphelins, car ils ne sont pas d'âge à rapporter au nid legibierpaternel.Mêmesortest lanôtre, à moi, à elle, Electre: en nous tu peux voir des enfants sans père, tous deux égalementbannisdeleurmaison. Si tu laisses mourir cette couvée d'un père qui jadis fut ton prêtre et te combla d'hommages,

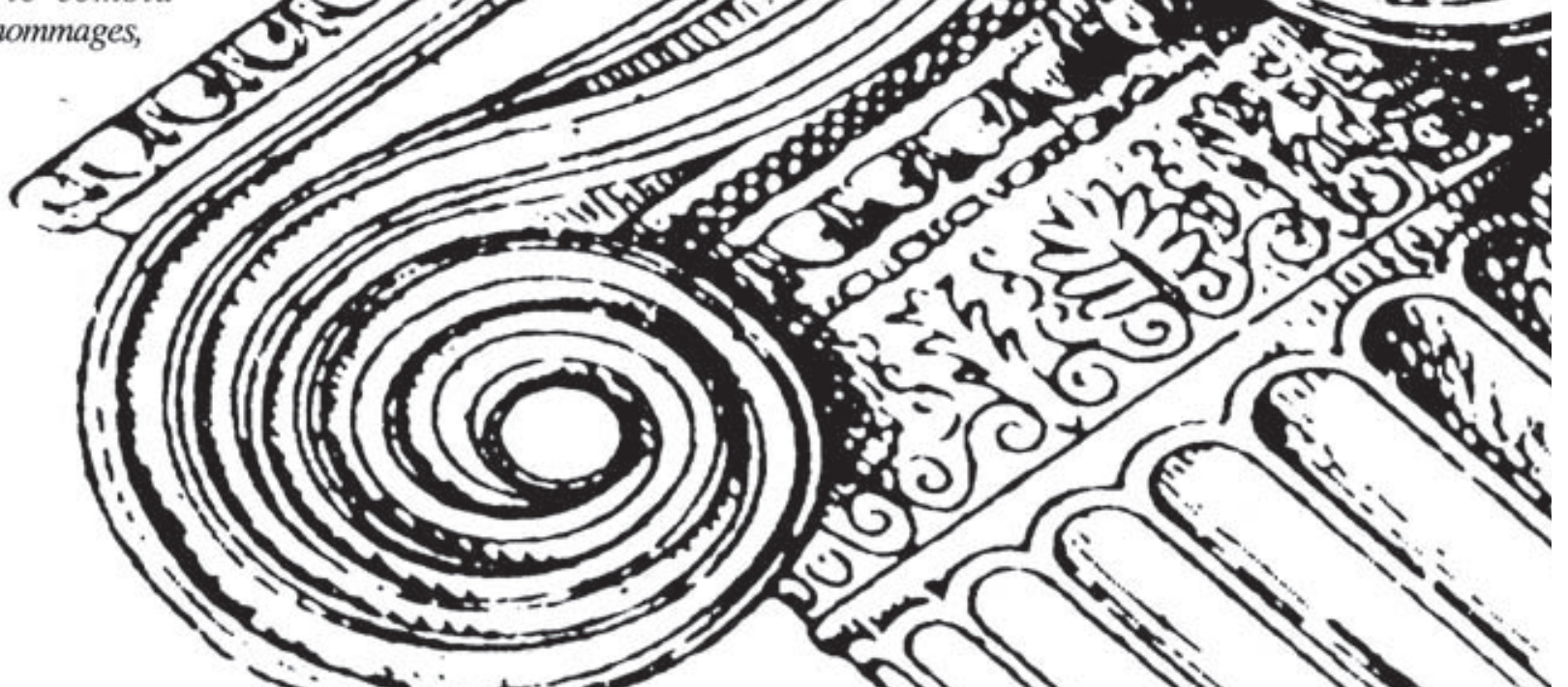

où trouveras-tu donc une main aussi large à t'offrir de riches festins? Si tu faisais périr la race de l'aigle, tu ne saurais plus envoyer à la terre de signes qu'elle accueille avec foi; et, de même, si tu laisses sécher jusque dans ses racines cette race royale, qui donc servira tes autels dans les jours d'hécatombes? Protège-nous: notre maison est bas, tu peux relever sa grandeur, toute déchue qu'elle semble aujourd'hui" (v. 247-263).

Pois bem: a luta da águia com a serpente constitui um topos arquetípico do imaginário grego, presente na literatura clássica. $\mathrm{O}$ confronto entre esses dois animais aparentemente tão diferentes parece ter impressionado desde sempre os humanos. E, no entanto, há secretas afinidadesentre os dois, sua relaçãose dá em mais de um nível, desde os avatares fálicos de serpente e de pássaro, até, na polarização pássaro/serpente, a dialética entre o ser da terra, que adere ao solo, rastejante, e o ser do ar, que se eleva em vôo, buscando alturas. No arco tensionado e sinuoso da serpente que arma o bote, prefigura-se a ave pronta a alçar vôo, na concentração de energia que precede o decolar. Não é para Valéry que a serpente é um "réptil aux extases d'oiseau"?

Mas volto aos anti-

gos. $\mathrm{O}$

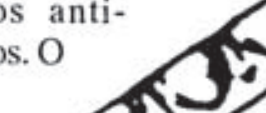
Da Adivinhaçílo atrawts do So nho, que os sonhos tếm uma natureza demoniaca, e nâo divina.

9a Karl Reinhardt. Eschyle Euripide, trad. E. Martineau. Paris, Ed. Minuit, 1927.p. 141.

9b Serpente: o termo grego aqui é echiona. 
estudo que faz Jean Dumortier (9c) sobre as imagens na poesia de Ésquilo sugere uma pista interessante: buscar em autores significativos, entre os clássicos, a quais realidades de conhecimento científicode posse dos gregos poderiam corresponder as imagens da poesia. É assim que ele rastreia essa imagem em Aristóteles e Plínio, o Antigo. Vejamos o que diz Aristóteles na sua História Natural dos Animais (10): “ L'aigle et le serpent se font la guerre, car l'aigle fait des serpents sa nourriture" (H.N.A., IX, L, II, 3); "Les serpents sont de plus serviles et tendent des embûches" (H.N.A., I, 1, 14).

Quanto a Plínio, o Antigo (11), autor dessa espécie de enciclopédia para a história da ciência na Antigüidade, que é sua História Natural, após ter contado o combate da águia e do cervo, acrescenta:

"La lutte avec le serpent est plus vive et beaucoup plus incertaine, bien qu'elle sepasse dansl'air. Le serpent recherche les oeufs de l'aigle avec une avide méchanceté; l'áigle pour cette raison l'enlève partout où il l'aperçoit; celuicidesesnoeudsmultiples luilieles ailes ets'enlace tellement àluiqu'ilstombent tous deux" (H. N., X, 5).

É assim que se configura a serpente, nesses textos "científicos": caráter servil, propensão às ciladas; ávida maldade. Mas também em passagens da épica e da lírica o mesmo padrão se verificará: na Odisséia, quando Heitor espera Aquiles com uma fria cólera, é a serpente que espreita o viajante. E o poeta lírico Teognis faz dela o símbolo do amigo pérfido: "Va-t-en avec la haine des dieux, et des hommes la défiance tu portes dans ton sein un froid serpent bigarré" (v. 601).

Chegando aos trágicos, J. Dumortier levanta essa imagem na Antígone de Sófocles: "Et toi aussi, comme une vipère qui se glisse dans mon palais, à mon insu, pour me sucer le sang" (v. 531). Mas será Ésquilo, principalmente, que apresentará a maior gama de exemplos: nas peças Sete Contra Tebas, Os Persas, Os Suplicantes, a imagem surge, com a conotação de "serpente cruel", "serpente assassina", "hóspede funesto para a ninhada". Ejá na primeira peça da trilogia que nos ocupa, Agamenon, Ésquilobrindará Clitemnestra com oepíteto de serpente:

"Femelle tueusedumâle, jevoisenelle...

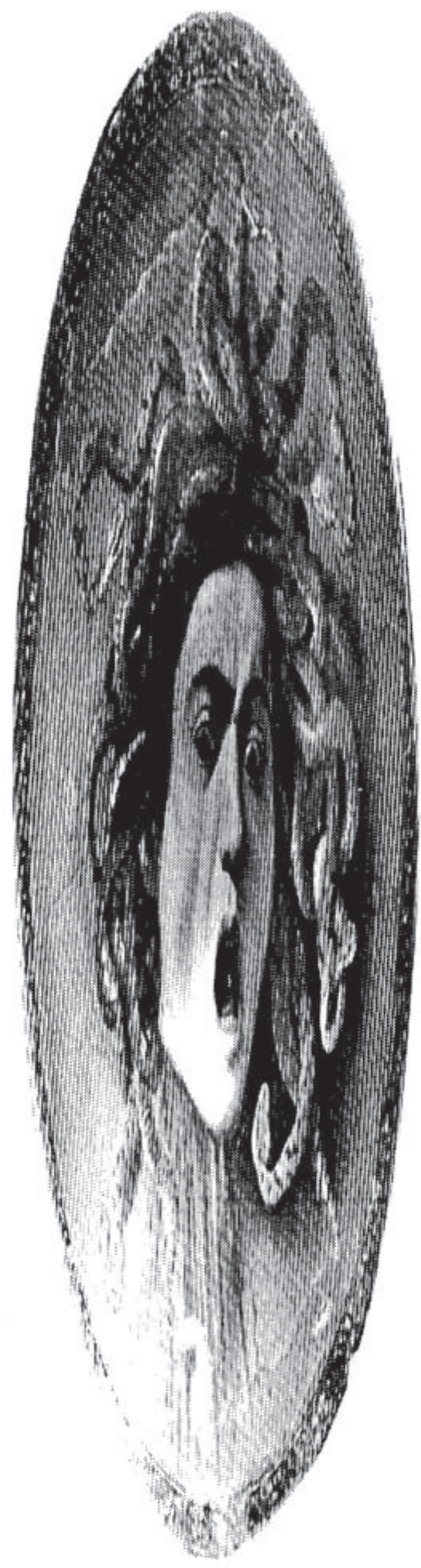


De quelle monstre odieux - dragon à deux têtes, Skylla gîtée dans les rochers, fléau des marins - devrai-je emprunter le nom pour donner celui qu'elle mérite à cette mère en furie, sortie de l'enfer, qui contre tous les siens ne respirera que guerre sans trêve" (v. 1233).

Cassandra chama aqui a rainha de "amphisbaina" - uma serpente de duas cabeças, da qual, segundo a referência de J. Dumortier, Plínio dirá: 'L'amphisbène a deux têtes, c'est à dire que par la queue, comme si un orifice seul était trop peu, s'écoule le venin" (H. N., VIII, 35).

Todas essas utilizações da metáfora da serpente remetem para o delineamento da característica fundamental da víbora como oanimal por excelência da perfídia, que mata aquele que a aquece ao seio, que se insinua: Clitemnestra matando à traiçăo o marido que retornara à casa - mas também Orestes entrando no palácio através de um estratagema e assassinando a mảe, como se verá mais adiante.

E assim estamos de volta ao sonho que estrutura a peça. Dizem unanimemente os helenistas que se ocuparam do assunto, que Ésquilo ter-se-ia inspirado, para a construção do sonho de Clitemnestra, no poeta Stesícoro (que viveu entre VII e VI A. A.), que também compusera uma Orestíada em vários cantos, dos quais só nos restam alguns versos. Pois bem, um dos fragmentos deStesícoro, de sua Orestíada, dizo seguinte, relativo a Clitemnestra: "Elle crut voir un serpent (12) qui s'avançait sur elle, le haut de la tête ensanglanté, puis il se transforma, et ce fut le roi, le Phisthènide qui apparut" (13).

O Plistenida é Agamenon, descendente de Plisteno. A rainha assassina vê em sonhos o marido ferido avançar sobre ela, sob a forma de uma serpente com a cabeça ensangüentada; e depois a serpente se transforma no rei. Já falei da associação fundamental, para os gregos clássicos, de "serpente" como animal ctônico, representante do mundo das potências infernais. Ejá que estamos na metáfora de um sonho, vale recorrer, de novo, à Oneirocrítica de Artemidoro: "Le dracon signifie roi à cause de saforce, temps à cause de sa longueur..." (II, 12-13).

Mas há ainda uma outra interpretaçăo do oneirocrítico, em que o elemento sexual assume oprimeiro plano. Falando do sonho de "parir uma serpente", Artemidoro inten- ta mostrar que o importante é achar analogias (14) (pois o princípio analógicoé oque rege a decifraçāo alegórica), levando-se em conta operfil(humanoe social)dosonhante. Assim, ele dá várias "interpretaçōes" para esse mesmo sonho, e uma delas nos interessará de perto, por causa das ressonâncias que provoca:

"Une autre (femme) eut le même rêve et son fils devint un débauché plein d'impudence et il viola nombre de femmes en ville: le serpent en effet se faufilant par les trous les plus étroits, cherche àéchapperaux regards deceux qui l'épient. En outre la femme était plutôt lascive et se prostituait" (IV, 67).

Voltemos a Stesícoro, que nos fornece um sonho com uma metáfora decodificada no próprio sonho: a serpente se transforma no rei. Ésquilo, que indubitavelmente aí se inspira para sua metáfora, mantém a polivalência da imagem. Pois no sonho de Ésquilo, a serpente que, parida pela rainha, the morde o seio (interpretada por Orestes como sendo ele próprio) na realidade é uma grande condensaçắo. $\mathrm{Na}$ medida em que Clitemnestra sonha ter parido a víbora, serpente diz respeito, inegavelmente, a Orestes; mas como serpente é o animal ctônico por excelência, deve referir-se a um morto (e é essa, como já observei, a interpretação da própria Clitemnestra):é Agamenon. Essa identificação de pai e filho faz-se de maneira muito forte no âmbito da imagem: a serpente - e aqui já se impôs o viés da psicanálise - é o pênis de Agamenon penetrando a mulher, ao mesmo tempo que é a criançafalosendo parida (15); enquanto que sugarmorder o seio é ao mesmo tempo amamentação e coito sádico (16). Além disso, a serpente que, parida pela mulher, lhe morde o seio, é uma representação estilizada do uruboro (serpente que morde a própria cauda), figuração da totalidade. $\mathrm{O}$ círculo se fecha, recompondo a unidade mãe-filho. E no momento em que Orestes interpreta o sonho de sua mãe - o momento de "a serpente sou eu!" - ele ao mesmo tempo se identifica com seu pai, o morto que surge, armando vingança, e com sua mãe, a víbora pérfida e assassina. Nesse jogo intercambiante de funçôes, em que a serpente, que fora a assassina de Agamenon, agora é o assassino de Clitemnestra (pai e filho ao mesmotempo), nesse momento em que Orestes endossa o sonho de sua mãe, e

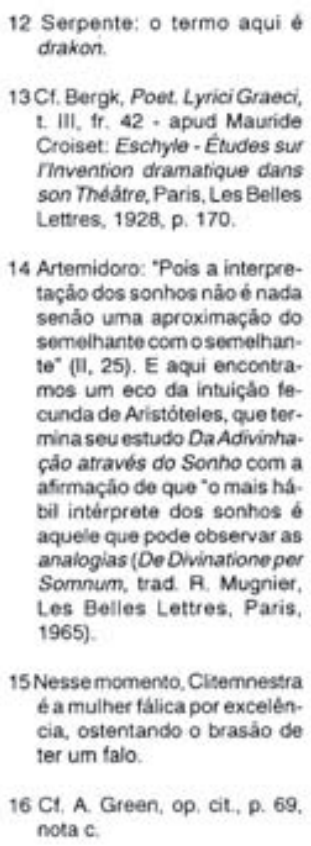

15 Nessemomento, Clisemnestra é a mulher falica por excelên. cia, ostentando o brasảo de ter um falo.

16 Ct, A. Green, op, cit, p. 69. nota $C$. 
que na produção onírica de Clitemnestra ele inscreve seu próprio desejo - nesse momento Orestes sonha o sonho de sua mãe. E esse é um sonho edípico. No entanto, o "sonho de Édipo" (é sob essa rubrica que Artemidoro de Daldis dedica um longo capítulo da Oneirocrítica aos sonhos de relaçāo sexual com a mãe) nāo há que ser interpretado, necessariamente - aqui nāo há nenhuma blague -, edipianamente. Pois no imaginário clássico relação sexual com a mãe pode ser decodificado como sonho de tomada de poder(17). A mãe significa "pátria", diz Artemidoro, e sonhar que se possui a mãe significa possuir ou repossuir a pátria. E ainda: "outre celà, après ce rêve, le voyageur sera ramené dans sa patrie et celui qui est en dispute sur les biens de sa mère gagnera son procès, ayant jouissance, non du corps de sa mère, mais de ces biens" $(\mathrm{I}, 79)(18)$. Estamos aqui em pleno arquétipo cultural da relação sexual com a mãe enquanto "retomada do poder" - aliás a interpretação antropológica dos helenistas do ato de Édipo (19). Dessa perspectiva, o filho exilado e alijado do poder pela mãe assassina do marido volta e se reinveste dos seus direitos. Mas este ato só será passível de ser realizado através da astúcia, de estratagemas, pois se trata de um combate desigual: será a luta da "couvée de l'aigle" contra a serpente. Só através do dolo (o termo é grego: dolos) Orestes poderá vencer Clitemnestra, por meio de uma armadilha: ele também deverá tornar-se serpente. (E veremosem seguida, em todos os sentidos.) O estratagema que ele urdirá para insinuarse no palácio e poder abordar a rainha e Egisto é apresentar-se como um estrangeiro: ele e seu amigo Pilade disfarçados como hóspedes, imitando o sotaque de Fócida, seriam introduzidos no interior do palácio. Pois este é o plano de Orestes, para Egisto eClitemnestra: "Qu'aprèsavoirimmolépar la ruse un héros révéré, de la ruse victimes à leur tour, ils soient pris et périssent dans le même filet" (v. 556).

Assim, tal como o "hóspede funesto", Orestes consegue através do dolo insinuarse no palácio, ser hospedado como amigo, penetrando nos aposentos que de outra maneira the permaneceriam vedados, e, assim como a serpente, morder o seio que a alimentara.

O termo grego, usado por Orestes ao interpretar o sonho de Clitemnestra, foi ekdrakontotheis d'ego: "eu, transformado em serpente", a matarei. $\mathrm{Na}$ firme decisão de realizar o sonho de sua mãe, Orestes diligencia por transformar-se em serpente. A primeira condição para tanto seria pertencer ao mundo subterrâneo, mundo infernal, espaço dos mortos: ele inventará, assim, a mentira da sua morte: contará à rainha que, ao se pôr a caminho para Argos, fora encarregado por Strophios da Fócida (em casa de quem abrigava-se Orestes) de dizer à família de Orestes que ele morrera: "A cette heure, lesflancsd'uneurned'airain enferment ses cendres pleurées comme il convient" (v. 687).

Anotícia da morte do filhode Agamenon faz de Orestes um morto. Identificando-se com seu pai na morte, ele poderá ser simbolizado pelo animal ctônico que é a serpente; utilizando-se do dolo, poderá ser figurado pelo símbolo da perfídia; assumindo o lugar do pai, na sua plena dimensão fálica, ele poderá realizar o coito sádico com a mãe. Aliás, essa identificação de Orestes com o pai na morte já tinha sido indicada nos versos iniciais da tragédia, na referência ao sonhode Clitemnestra: "sousterre, lesmorts âprement se plaignent et s'irritent contre leurs meurtriers" (v. 39).

E aquele plural, "os mortos", que poderia ter sido lido como Agamenon e Cassandra, assassinados na primeira peça da trilogia, agora pode ser identificado enquanto pai e filho: o pai morto e o filho apresentado como morto e, num certo sentido, "morto para sua mâe".

Mas há ainda uma cena, já posterior ao assassinato de Egisto, em que essa imagem - e quase a mesma formulação, ao menos no que se refere a esse plural, "os mortos" retorna. Atraídas pelos gritos de um escravo, Clitemnestra sai do gineceu:

"Clyt. - Quest-ce? de quelles clameurs remplis-tu la maison?

Serviteur. -Jedisquelesmorts frappent le vivant.

Clyt. - Malheur sur moi! Je comprends le mot de l'énigme.

Nous allons périr par la ruse, ainsi que nous avons tué" (v. 885-889).

A ambigüidade aqui é instigante, pois o enigma a que se refere Clitemnestra (toepos ainigmáton) pode dizer respeito à última fala do servo, "os mortos abatem o vivo" (na situação em que Agamenon assassinado e Orestes dado como morto matam Egisto; ou melhor, Orestes é o braço armado de seu pai assassinado) ou pode referir- 
se a seu sonho (não foi Freud que chamou o sonho de um rebus, um enigma?). As palavras da rainha podem significar que ela teve, naquele exato momento, o insight a respeito da interpretaçāo exata de seu sonho, do "enigma" de uma serpente que, parida por ela, lhe morde o seio. Em outras palavras, é como se só então ela adquirisse a percepção da gama de significaçōes daquela metáfora: o símbolo da perfídia $(\mathrm{em}$ que provavelmente sua consciência culpada se reconheceria com facilidade) aplicado ao próprio Orestes; a identificação do marido e do filho no animal que representa o mundo dos mortos; e o assassinato dela própria, numa relação de correspondência com seu próprio crime, numa armadilha. A serpente que ela fora, matando o próprio marido, agora perecerá, "por dolo", à māo do filho transformado em serpente. (Estamos aqui em plena encruzilhada da cadeia de significantes.) É esse o mot de l'énigme que, no entanto, deverá esperar ainda alguns versos para ser cabalmente explicitado.

Pois a cena mais patética ainda está por vir. A porta central se abre, e māe e filho se defrontam, Orestes com a espada na mão; Clitemnestra lamenta-se pela morte de Egisto. E, à alusão feita por Orestes ao amor que ela devota a seu amante, Clitemnestra, rasgando suas vestes, lhe mostrará o seio (20): "Arrête, ô mon fils! respecte, enfant, ce sein, sur lequel, souvent, endormi, tu suças de tes lèvres le lait nourricier" (v. 896).

É esse o momento em que o matricida deixa cair sua espada; mas após a intervenção do amigo Pilade, que the rememora o oráculo de Apolo, a lealdade, os juramentos, Orestes se recupera da hesitação, insiste em pontuar a ligação erótica da mãe com Egisto (21), e trava com a rainha um diálogo tenso e crispado, que culminará com o matricídio:

"Clyt. - Veux-tu vraiment tuer ta mère, ô mon enfant?

Oreste. - Cen'est pas moi, c'est toi qui te tueras toi-même (22).

Clyt. - Prends garde: songe bien aux chiennes de ta mère.

Oreste. -Et celles de mon père, où les fuir, si j'hésite?

Clyt. - Ah! je suis là, vivante, à prier un tombeau!

Oreste. - Le sort fait à mon père te condamne à la mort.
Clyt. - J'aurai donc enfanté et nourrice serpent!

Oreste. - La terreur de tes songes fut un devin sincère. Tu tuas ton époux, meurs sous le fer d'un fils".

As palavras absolutamente finais de Clitemnestra nessa tragédia são a sua interpretação cabal do sonho que ela tivera, e que vê realizando-se: "J'auraidoncenfanté et nourri ce serpent?' (v. 928).

O sonho de Clitemnestra, sonhado por Orestes, é por ele efetivado. E no momento mesmo desse ato, ele tem a consciência de estar concretizando o sonho: "O terror dos teus sonhos foi um adivinho sincero".

Mas, se pensávamos que com a compreensão do "enigma", por parte de Clitemnestra, a metáfora da serpente já se teria expandido em sua plena medida, estávamos enganados. Pois se continuarmos a rastrear essa imagem, vemos que após esse momento decisivo que é a realizaçāo do matricídio e a interpretação do sonho pela rainha no instante mesmo que tal sonho se realizava, em passagens posteriores, portanto, a essa cena, voltam ainda as imagens de serpente - mas com uma nova possibilidade de significação.

No primeiro surgimento dessa imagem após a cena central docrime, nos versos 991 ss, quando Orestes mostra ao povo os dois cadáveres, nada se inova na metáfora; apenas retoma-se o sema da perfídia e da "ávida maldade" que serpente - aqui aferida a Clitemnestra - representa:

"Mais celle qui imagina telle horreur contre un homme dont elle avait porté les enfants sous sa ceinture - fardeau d'amour jadis, de haine aujourd'hui, il le prouve lui-même! - que te semble-telle? Murène ou serpent? (23) un être en tout cas capable d'infecter sans morsure, au simple contact, par le seul effet de son audace et de son orgueil naturels..."

Mas nas duas passagens seguintes - e últimas - em que essa metáfora se fará presente, um novo sentido começará a imporse. Eé a figura da serpente - com a acepção que passo a desenvolver - que será o verdadeiro gatilho para a loucura de Orestes.

Dizo Corifeu: "Tuas triomphé: ne mets pasteslèvresauserviced'unlangage amer: ne te maudis pas toi-même, le jour où tu as délivré le pays argien, en tranchant d'un
20 Cena em que André Green, como náo podería deixar de ser, vê mais que uma tentati. va de provocar piedade, um ato de seduçăo da rainha "oi olle s'offre on fait aux tontations soxuollos" (op, cit. p. 66).

21 Numa cena posterior, após o duplo assassinato, Orestes mostra ao povo os dois cada. veres e insiste, mais uma vez, nessa morte conjunta, uma espócie de "pacto de fidalida de" que tora aseim selado, prolone fora assim selado. Egisto e Clitemnestra, perpe tuando-a.

22 Fala em que se pode vislum. brar a reversibilidade do refe. rente da metáfora da serpente. Mol/tori quem vai matar a serpente; serpente fora a serpente, e serpente fora Clitemnestra.

- La métaphore. bien plus précisement. est te surgissement dans une chaine signifiante donnée d'un signifiant venu d'une autre chaine ce signifiant autre chaine, ce signifiant manchissant la barre (résistante') de ralgorithme pour troubler. de sa 'disruption', te signifie de la premiere chaine, oú il produrt un effet de non sens" - dizem Todotov-Ducrot relando Todor ov.Ducrot relendo Jakobson a luz de Lacan (Oictionnaire Encyclopedique des Sciences du Langago. Paris, Seuil, 1972, p. 442).

23Serpente: otermo original aqui é echidna. 
24 Serpente: o termo aqui o drakon.

25 A traduçáo integral seria: "Ah ahl cativas, a.. ali, ali... mulhe res, semelhantes as Górgonas, vestidas de ne. gro...:

$26 a$ Das trés Górgonas, Stheno, Euryale e Medusa, geralmente dá-se onome de Górgona esta última, sendo Medusa considerada a Gorgona por excolencia. Nascida do sangue com que a mutilaçáo de Urano impregnou a terra. Górgonatem ainda a caracte. ristica de parir pelo pescoço.

26b Comobemobservou Maurice Croiset, em seu ensaio "Les Euménides", in Eschyle Etudes sur I'invention Dramatiguedans son Thedtre. Paris Les Belles Lettres. 1928, P. 243 .

27 Jean Pierre Vernant, La Mort dans les youx - Figures de rAutre en Grece Ancienne. Artémis, Gorgó, Paris. Hacherte, 1985, p. 39

28 Freud, "O Estranho" ("Das Unheimlich"), vol, XVII das Obras Completas, Filo de Janeiro, Imago, p. 305.

29 Freud, "O Estranho", op. cit. p. 304.

30 Freud, "A Cabeça da Medusa", wol. XVIli das Obras Com. pletas, Rio de Janeiro, Imago. p. 329.

31 Para Vernant, oque aterroriza em Gorgo $b$ a alteridade absoluta, o radicaimente "outro" que ela representa, 6 oduplo:

La face de Gorgó est un mas. que: mais au lieu qu'on le por. te sur soi pour mimer lo diev. celte figure produit lefffet do masque simploment en vous regardant dans les yeux. Comme sice masque n'ava Quitu botre visage, no s'bta fxer an face de vous, comm votre ombre ou votre reflet sans que vous pulssiez vous en detacher. Cestuotre regard oul est pris dans lo masque. La face de Gorgó est I Autre. le double de vous món. trouble do vous mome. votre figure comme une image dans le miroir (ce miroir oú les Grecs ne pouvaient se vair que de face et sous forme d'une simple tête), mais une image Quiserat d la fois moins etplys que vous mime, simple refle etrólailité crau-delà, une image quivous happerait parce qu'a: lieu de vous renvoye seviement lapparence de votre propre figure, de réfracter votre regard, elle eprosenterait, dans sa reproson terait, dans sa grimace, Thorreur terminante une allerite radicale. laquele vous alliez vous -méme vous identifier, en devenant pierre.

Regarder Gorgó dans les yeux, c'est se trouver noz hez avec flau deld dans sa - avoc raudela dans sa e regard avec roeil qui no cessant de vous fixer est ta négation du regard, accueili une fumierre dont l'bclat aveuglant est celwi de la nu. Quand vous dtvisagez Gorgo coup heureux la tête de ces deux serpents" (24) (v. 1044).

Aproximamo-nos dos versos finais da peça, chegando ao fim do rastreamento da imagem da serpente, que eu me tinha proposto. Pois bem: à evocação das cabeças cortadas das duas serpentes, o delírio de Orestes irrompe. E à indicação cênica "Oreste, qui se dirigeait vers la sortie de gauche, recule tout à coup épouvante", seguem-se as falas absolutamente finais do matricida:

“-Ah! ah!captives...là, là... desfemmes, vêtuesdenoir, enlacées de serpentssans nombre... Je ne puis plus rester.

Vous ne les voyez pas, vous, mais, moi, je les vois. Elles me pourchassent, je ne puis plus rester" (v. 1049 ss).

Assim, ao término da tragédia, será a serpente - de um lado, na alusâo do corifeu às serpentes de cabeças decepadas (imageminequívoca de castração); de outrolado, na visão das Eríneas (mulheres que têm serpentes em lugar dos cabelos) - que desencadeará a loucura final de Orestes.

É estranhíssimo que o tradutor francês do texto da Belles Lettres que venho compulsando, Paul Mazon, tenha, relativamente aos versos 1049 ss, vertido para o francês, como citei, “.... des femmes, vêtues de noir, enlacées de serpents sans nombre...", e tenha deixado de explicitar aquilo que, no grego, é absolutamente explícito, ou melhor, literal: a referência às Górgonas. Faltou, no texto francês, inexplicavelmente, a traduçâo dos termos Gorgónondiken, "à maneira das Górgonas" (25). Mas na realidade essa traduçāo literal apenas explicitaria (e, para os meus propósitos, reforçaria) uma alusão que a imagem das Eríneas sozinha já comporta. Há analogias figurativas evidentes entre as Erínease a Górgona Medusa (26a), a partir de sua característica básica de terem a cabeça enlaçada de serpentes. Aliás, a identificaçãodas Eríneas, divindadesvingadoras, com as Górgonas é feita pelo próprio Ésquilo (26b), na peça seguinte da trilogia, As Eumênides. Com efeito, nos versos iniciais dessa tragédia, a Pítia de Delfos, diante do templo de Apolo, depara-se com Orestes, o matricida suplicante, acompanhado de um bando de Eríneas: "En face de l'homme, une troupe étrange de femmes dort, assise sur les sièges. Mais que dis-je, des femmes?
Des Gorgones plutôt..." (As Eumênides, v. 370).

Ora, Jean Pierre Vernant, um helenista acima de qualquer suspeita de delírios interpretativos psicanalíticosnãodeixou de apontar na máscara da Górgona uma "representação crua e brutal" do sexo feminino. Em seu instigante livrinhoLaMort dans les yeux, em que se propōe a estudar a Alteridade, a experiência doOutrona Grécia Antiga, Vernant reserva um grande espaço ao estudo dessa máscara de horror, a Górgona Medusa - que, na Ilíada, figura na égide de Atena e no escudo de Agamenon:

"Mais cette terreur dont elle incarne la présence, qu'elle mobilise en quelque sorte, n'est pas 'normale': elle ne tient pas à la situation particulière de danger dans laquelle on se trouverait. C'est l'effroi à l'état pur, la Terreur comme dimension du surnaturel. En effet cette peur n'est pas seconde ni motivée, comme celle que provoquerait la conscienced'un péril.Elleest première" (27).

É muitíssimo curioso que Vernant, que insiste na irracionalidade desse terror, que cita "aspects marqués d'insolite et d'étrangete' (p. 79); que fala, literalmente, em "inquiétante étrangete" (p. 32), em nenhum momento endosse as conclusōes de Freud sobre as raízes do intenso pavor que a visão de Gorgô propicia, e não confirme a interpretaçäo psicanalítica do terror de castração ligado à visão da cabeça da $\mathrm{Me}$ dusa.

Mas antes de referir essa última interpretação (presente no texto de Freud "A Cabeça da Medusa", de 1922, talvez seja o caso de me deter na idéia correlata, de estranheza - que nāo poderia deixar de remeter ao "Unheimlich". Com efeito, no famoso texto de 1919, Das Unheimlich, Freud fornece subsídios para que possamos conjugar, num mesmo olhar, o estranho, insólito (mas, ao mesmo tempo, extremamente familiar) e o duplo. O estranho, diz Freud, é aquela categoria do assustador que remete ao que é conhecido, de velho, e há muito familiar. Sendoa palavra alemãunheimlich oopostode heimlich (Heim=lar), seríamos tentados a concluir que aquilo que é "estranho"é assustador precisamente porque nāo é conhecido e familiar. Mas Freud chega através do estudo de uma série de casos - à conclusão (confirmada, mais tarde, por um 
exame do uso lingüístico) de que, por vezes, instaura-se uma ambivalência, e unheimlich coincide com o seu oposto, heimlich, sendo que o estranho pode provir de algo familiar que foi reprimido, ou, para se tomar a definição de Schelling, o estranho é "algo que deveria ter permanecido oculto, mas veio à luz".

"Acontece com freqüência que os neuróticos dosexo masculinodeclaram que sentem haver algo de estranho no órgão genital feminino. Esse lugar unheimlich, noentanto,éa entrada para oantigo Heim (lar) de todos os seres humanos, para o lugar onde cada um de nós viveu certa vez, no princípio. (...) Nesse caso, também, o unheimlich é o que uma vez foi heimlich, familiar; o prefixo un ('in') é o sinal da repressāo" (28).

Assim, desse viés, explicar-se-ia o desencadear da loucura de Orestes, quando o coro alude às serpentes de cabeças decepadas e quando vê as Eríneas, mulheres "semelhantesàs Górgonas", com cabeleiras de serpentes.

Apesar de já no texto sobre o "Unheimlich" Freud ter tratado da "estranheza" que membros arrancados, cabeça decepada, mão cortada pelo pulso, etc., apresentam, concluindodaíque "essa espécie de estranheza origina-se de sua proximidade como complexo de castração"(29), será no pequeno texto "A Cabeça de Medusa" que ele desenvolverá mais completamente o tema em questão. Propondo-se aí a uma interpretação da horripilante cabeça decapitada, diz Freud:

\footnotetext{
"Decapitar = castrar. O terror da Medusa é assim um terror de castração ligado à visão de alguma coisa. Numerosas análises familiarizam-nos com a ocasião para isso: ocorre quando um menino, que até entāo não estava disposto a acreditar na ameaça de castração, tem a visãodosórgãos genitais femininos, provavelmente os de uma pessoa adulta, rodeados por cabelos, e, essencialmente, os de sua mãe.
}

Os cabelos na cabeça da Medusa são freqüentemente representados nas obras de arte sob a forma de serpentes, e estas, mais uma vez, derivam-se do complexo de castração. Constitui fato digno de nota que, por assustadoras que possam ser em si mesmas, na realidade, porém, servem como mitigação do horror por substituírem o pênis, cuja ausência é a causa do horror. Isso é uma confirmação da regra técnica segundo a qual uma multiplicação de símbolos do pênis significa castraçăo" (30).

Mas eu havia dito que era extremamente curioso que Vernant - que fala literalmente em "inquiétante étrangetê" (o termo da tradução francesa para "Das Unheimlich")- não endosse a interpretaçāo freudiana para o horror provocado pela máscara da Górgona (31). Tanto mais curioso quanto o próprio Vernant alude a razões infantis desse pavor, citando um interessantíssimotextodeFédon dePlatão, para quem terrores desse tipobrotam, nohomem, da criança que ele foi. Refere Vernant que Platão, evocando o medo infantil de que o vento muito forte possa dispersar a alma à saída do corpo, diz: "il y a au-dedans de nous je ne sais quel enfant à qui ces sortes de choses font peur. Cet-enfant-là, tâche que, dissuadé par toi, iln'ait pas de la mort la même crainte que des mormolúkeia, des croquemitaines" (Fédon, 77, 2) (32).

Para escorraçar tais temores, observa entâo o Sócrates do diálogo platônico referidopor Vernant (33): "é preciso um encantador bem-sucedidoe uma encantaçāoquotidiana até que a criança seja acalmada pelos encantamentos". (O que não deixa de ter ressonâncias significativas junto àqueles que "confessam" a psicanálise...)

Da perspectiva do Fédon de Platâo, então, esses medos irracionais poderiam radicar naquilo que, em nós, subsiste de infantil.

Não seria essa uma explicação para o inenarrável terror de Orestes - terror de castraçâo-após ter matado Clitemnestra, diante da evocação das cabeças decepadas das serpentes e da visão alucinada das Eríneas, Gorgónon diken, cabeças de mulher com cabeleiras de serpentes?

Assim, creioque se pode apontar, em As Coéforas, que o rastreamento da metáfora fundamental que é aí agenciada - a serpente, núcleo do sonho de Clitemnestra, mas figura presente do início ao fim da tragédia - mostra que seu leque de significações vaise desdobrando e ampliando, numa riqueza insuspeitada de significados. E aqui como nunca, fica provado que metáfora é condensação. Condensação: um dos processos fundamentais da elaboraçãoonírica... e poética. c'est elle qui fait de vous ce miroir oú en vous transformant en pierre elle mire sa terrible face et se reconnaOt alle. mime dans le double, lo fantómeque vous átes devenu dets fors que vous affrontiez son oeil, Ou, pour exprimer en d'autres termes. cette reciprocité, cotte symútrie trangement indealo thangome indgalo do thomme of du diec, ce que vous donne à voir le masque de Gorgó, quand vous en btes fascind, c'est vous-móme. vous-meime dans l'au-dela. cette tête vêfue de nurit, certte face masquede dinvisible quil dans rooil de Gorot, se retutie ta vínite do votre propre fou. l. (J. P. Vetrant, op. cilgu. (J. P. Vernant, op, cit. P. 82)

32 Apud J, P. Vernant, op. cit. P. 61.

33 Instigado por essa ideia de enraizar terroces irracionais num residuo infanbil, Vernant vai retomar o dossié de Erwin Fohde (Psyché, Lo Culte de rame chez les Grecs et feur croyance à rimmortalté $\mathrm{Pa}$. ris, 1928, app. 5, pp. 607-11) procurando, no nivel das ex. presscos pcpulares e do universo intantil, a expressáo da mesma poténcia de Terror que a máscara de Górgona pare. ce encarnar, em outras figu. ras atormentadoras da infin. cia E uma dessas figuras Mormó, também uma másca. momo, ra, que, em Tobcrito, evoca cabeça de um cavalo. Veja mos o próprio Vernant: "A son entant, pour rettrayer, et le faire taire, la mére lance: "Mormó, le cheval mord (dokneihiposs) Cosmonstres

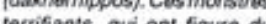
Crolope qu ou cheral, son Cyclope au du cheval, son censés s'emparer des entants. les ravir, les dévorer, les vouer da la mort (Vernant: La Mort dans les youx, op. cit., p. 61). E pouco provável que leitores afeitos aos textos que iencres. aleitos aos textos da psicaná. queno Hanse de seus medos. 